\title{
Evaluation of Location Aspect in Buyer's Decision to Purchase Elite Residence in Medan
}

\author{
Elisabet Siahaan \\ Department of Management, \\ FEB USU \\ Medan, Indonesia \\ dr.elisabethsiahaan13@gmail.c \\ om
}

\author{
Khaira Amalia Fachrudin \\ Department of Management, \\ FEB USU \\ Medan, Indonesia
}

\author{
Magdalena L. Leonita S. \\ Department of Management, \\ FEB USU \\ Medan, Indonesia
}

\begin{abstract}
House is a basic need for human beings. Many developers prepare ready-to-livein houses for the community. Selection of each individual on his dream house or residence is a personal need and preference. The developer prepares the housing in fulfilling individual's preferences and needs. However, there are few developers who want to conduct customer surveys on preferences and expectations regarding the housing that has been bought when it can be a learning experience in the next housing development. This study is aimed to evaluate location factors in consideration of elite residence buyers in the city of Medan in aspects of accessibility, mobility, amenities, and environments. A total of 120 residence owners were randomly selected and participated in the study. The ranking scale and second order analysis are used to measure the importance of the location aspect from the buyer's point of view. The results indicate that the buyer of elite residence in Medan city is very concerned about the location aspect, especially the location that is free from flood and safe from crime. Housing accessibility also needs to be considered in selecting locations and developing housing in Medan city. Mobility is perceived as the least important factor in purchasing decisions due to the mobility of owners can be accommodated through good accessibility.
\end{abstract}

Keywords - Residence Purchase Decision, Location, Elite Residence Consumer, Housing Developer

\section{INTRODUCTION}

The residence is one of the basic human needs [1]. A place of residence is where a person takes shelter and spends some of his time. As a basic necessity, residence becomes one of the products that is always sought by every individual.
Housing is one form of property that provides benefits as a place to live. Housing is generally built by the developers who manage an area into living area for individuals who need it. In the economic context, developers are producers and sellers and potential buyers are potential customers.

Choice of residence of an individual is determined by the preferences and personal circumstances of each individual [2]. Demand on a housing will be influenced by the preferences of potential buyers. In the concept of demand, prices will rise when demand for a product is higher [3]. It is important for developers to be aware of aspects of the preferences of potential buyers in a residential building and determine a reasonable price for prospective buyers.

Studies on the topic of own property buyer behavior has been progressing since many years ago, especially in the context of developing markets $[4,5]$. The researchers agree that residence purchase decisions are generally based on the same criteria, although the level of importance of these criteria varies. The most important criteria in purchasing decisions housing in previous studies is the technical aspect, the functional and location aspects of a housing [6].

Location factors in the context of property valuation are very important. The majority of professionals in the field of real estate property will declare the term 'location, location and location' when answering a question that refers to the most important aspect in the assessment of housing [7]. Functional and technical aspects of the residential building itself become an important consideration factor for prospective buyers, but it is also important to consider the location aspect in building the market demand [8]. For example, the demand of an elite residence in a remote place will be far below the value of an elite housing located in the city center with seamless access to transport and complete with various public facilities and good schools. The difference between the views of prospective buyers to assess similar luxurious 
houses with different locations makes the location factor as an important consideration in building the perception of and demand for housing which will be built in a particular location.

The development of the literature in the housing assessment study also states that the assessment standard of housing is not only based on the functional and technical aspects of the housing alone, but the location factor of the housing itself. Studies conducted by Srour et al. [9] state that the value of the house (physical) and the value of the location of a housing are evaluated separately. The assessment of the location factor itself from the point of view of the researcher is progressing. Studies of Kolbe et al. [8] use the rating of the location as a reference of location factor assessment based on the geographical conditions of the site. Studies conducted by Huderek-Glapska and Trojanek [10] use the criteria of accessibility and transportation that meets the needs of households, businesses, and other aspects as a basic reference in assessing the location factor accompanied by noise pollution. Regardless, they have indicated that the location factor plays an important role in the reasonableness of the price in view of the potential buyer.

The growth of housing in Medan city is quite rapid. In 2017 alone, a lot of developers prepare a ready-to-live-in housing for the community. The Mayfair and Santa Fe are tangible evidence of the development of housing in Medan which were launchedin 2017 for the upper middle class. The developer investsa big fund to realize the housing, especially for the upper middle class. In this regard, it is important for developers to determine the appropriate location within the housing development. Renigier-Biłozor and Wiśniewski [11] in their study state that the developer focuses on some aspects in determining the location of the prospective housing, namely:

1. Condition suitability of land for housing

2. Available land area

3. Distance to markets and employment opportunities

4. Close proximity to school, household needs, university

5. Availability of health / hospital services

6. Availability of recreation areas such as parks

7. Condition of air pollution

Location factors refer to the accessibility, mobility and amenitywhich have previously been described in the previous research related to aspects of the location. The developer also makes this factor into consideration in selecting the location of the development. Environmental factor in this case is one factor that refers to the selection of housing development sites. Pollution consideration factor refers not only to air pollution in environmental aspect. Lake et al [13] state that the road improvement is visually intrusive and causes inconvenience through the noise of improvement activities. They make people become uncomfortable at that location. Mitkus and Šostak [14] also state the same thing related to regional development.

Relevant studies on the behavior of residential property buyers still underestimate this aspect of consideration from the buyer's point of view in choosing the residence, particularly in the middle to upper class housing. Upper middle class housing prices are quite high for society general income. Limited purchasing power makes the sale of residential units will be difficult to achieve, especially if it is not in line with the preferences of the buyer. This research becomes important in understanding the preferences of buyers of residential property, especially in the upper middle class.

The developer needs the preference information of potential buyers in terms of increasing the perceived value by the buyer [15]. For example, knowing if a buyer would be willing to pay more for parks and greening facilities provided by the developer [16]. Unfortunately, the developer rarely conducts a survey of residential buyers to know the factors considered in choosing the location of housing. Such information can be utilized for activities of the development in the future. This condition prompted the authors conducted a survey related to residence owner preferences in deciding to buy luxury residence (upper middle class) on aspects of housing location.

\section{RESEARCH OBJECTIVE}

This study invited owners of residences to provide a rating on the aspects related to the location of accessibility, mobility, amenity, and environmental conditions in the housing they occupy. The purpose of this study is to find the priority factors that must be considered by the developer in determining the location of the housing to be increasingly demanded by prospective buyers based on experience that occurred in previous residence buyers. Perceptions of potential buyers are used as a benchmark for assessing these location factors.

\section{LITERATURE REVIEW}

The scope of the location in the literature study is extensive.Literally, location refers to a place or place option. Within the scope of the housing assessments, the location factors are perceived in different points of view. Wojnarwsky et al. [17] use a geographic approach in assessing factors when choosing the location of housing programs. Kolbe et al. [8] use a quality approach in assessing the general location of the location factor in the value of housing. Appraisal Institute [18] provides the 
general guidein assessing the location referred to the concept of "location, location, location" within the meaning of the location as accessibility, mobility, and amenity. Andersson et al. [19] include the state of the environment in assessing the location. A summary of the evaluation of location factors is presented in Table 1 .

TABLE 1. Review of Location Factor Approach

\begin{tabular}{|l|l|}
\hline Researchers & Approach \\
\hline Wojnarwsky et al. (2017) & Geographical aspects \\
\hline Kolbe et al. (2013) & Location rating \\
\hline Andersson et al. (2010) & $\begin{array}{l}\text { Environmental conditions such } \\
\text { as road construction, facilities } \\
\text { and scenery }\end{array}$ \\
\hline Appraisal Institute (2008) & $\begin{array}{l}\text { Accessibility, Mobility, } \\
\text { Amenity }\end{array}$ \\
\hline
\end{tabular}

Kotler and Keller [20] state that the location is one of the forms of the marketing mix, place, which is where the choice of product marketing. In the context of the value of a housing, the location is defined as a function of 3L, 'location, location and location'. Willmore (21) believes that the location is a very important factor in shaping the value of housing in the minds of consumers. In the $3 \mathrm{~L}$ function, the location has three approaches:

\section{Accessibility}

Location in this case relates to the proximity of the housing location with the access to the main highway.

\section{Mobility}

Location in this case relates to the proximity between the housing location and daily necessities, e.g. workplace, children's school, market, and so on.

\section{Facility (Amenity)}

Location in this case relates to the proximity between the housing location with public facilities such as hospitals, terminals, and so forth.

Lundgren (22) adds the element of location such as the environment as an important aspect in the assessment of the location, especially from the perspective of consumers (residency). Therefore, this study includes elements of the environment in its implementation.

\section{RESEARCH DESIGN}

The team of researchers worked with the housing developers to obtain housing mapping used in the determination of a random sample with a random number generator in Microsoft Excel function of housing data collected. Samples that could not be contacted or refused to participate were replaced with the next random sequential number. Research was conducted in the upper middle class housings elected in Medan, namely Citra Garden, Citra Wisata, White House Garden, Perumahan Tasbih (I \& II), Royal Monaco, Gatsu Indah,Asoka Raya Regency and Johor Regency. A total of 120 selected residence owners were participated in this study.

Selected respondents were adults who had houses in selected housings. Data were collected through interviews and by using a research questionnaire. The questionnaire was developed by a team of researchers based on location factors studied, such as accessibility, mobility, amenity and location tailored to the housing situation of Medan. Questionnaires were grouped into two parts, namely the characteristics of respondents and respondents' opinion on the research variables. In the study of variables, the scale used is 5-scale Likert to measure the perception of respondents. The reliability of the previous instrument was tested on pre-research using thirty samples. The operationalization of the variables and the reliability of the instruments are summarized in Table 2.

TABLE 2. Variable Operationalization

\begin{tabular}{|c|c|c|c|}
\hline Dimensions & $\begin{array}{l}\text { Operational } \\
\text { definition }\end{array}$ & $\begin{array}{l}\begin{array}{l}\text { Number } \\
\text { of } \\
\text { Indicators }\end{array} \\
\end{array}$ & $\begin{array}{l}\text { Cronbach's } \\
\text { Alpha }\end{array}$ \\
\hline Accessibility & $\begin{array}{l}\text { Easy access of } \\
\text { housing } \\
\text { location }\end{array}$ & 3 & 0.892 \\
\hline Mobility & $\begin{array}{l}\text { The proximity } \\
\text { of housing } \\
\text { location to } \\
\text { important } \\
\text { locations such } \\
\text { as workplaces, } \\
\text { schools, } \\
\text { shopping } \\
\text { centers }\end{array}$ & 3 & 0.887 \\
\hline Amenities & $\begin{array}{l}\text { The } \\
\text { availability of } \\
\text { public } \\
\text { facilities near } \\
\text { the housing, } \\
\text { such as } \\
\text { hospitals }\end{array}$ & 4 & 0.901 \\
\hline $\begin{array}{l}\text { Environmental } \\
\text { Factor }\end{array}$ & $\begin{array}{l}\text { The } \\
\text { surrounding } \\
\text { environmental } \\
\text { conditions of } \\
\text { the housing } \\
\text { associated } \\
\text { with security, } \\
\text { pollution, } \\
\text { natural } \\
\text { disasters }\end{array}$ & 4 & 0.864 \\
\hline
\end{tabular}

Respondents had the freedom to express opinions collected as the additional information through the interview method. This information is important in assessing the perceptions and preferences of the owner of housing on the reasons they decided to buy the housing. 


\section{DATA ANALYSIS METHOD}

The questionnaire used in this study was divided into two main parts. In the first part of the data obtained were the characteristics of respondents. The data would be presented descriptively and analyzed to see the characteristics of the owner of the upper middle class housing in the city of Medan. In the second part, the data are sorted based on the ranking by using the total score of research respondents on each of the research indicators. Ranking obtained illustrated the scale of the interests of each aspect of the location assessed, data were analyzed using the second orderanalysis to see statistically the level of interest in each of these aspects of location factors assessed.

\section{RESULT AND DISCUSSION}

\section{A. Respondents'Characteristics}

The respondent's characteristic was used to review the characteristics of the research sample used to generalize the research results. The characteristics of respondents in this study were based on residence ownership status, current job, past education, how they occupied the residence, how long they had inhabited the house, as well as self-evaluation of the value of the house occupied.

\section{Respondents Based onOccupation}

Characteristics of respondents based on occupation could help a team of researchers in reviewing certain occupational groups who mostly chose a place to stay in luxury housing. Characteristics of respondents based on their occupations are summarized in Table 3.

TABLE 3. RespondentsBased on Occupation

\begin{tabular}{|l|l|r|}
\hline No & Occupation & $\%$ \\
\hline 1 & Government Employees & 10.00 \\
\hline 2 & Private Employees & 62,50 \\
\hline 3 & Professional & 5.83 \\
\hline 4 & Entrepreneur & 18.33 \\
\hline 5 & Others & 3.33 \\
\hline Total & & $\mathbf{1 0 0 . 0 0}$ \\
\hline
\end{tabular}

Table 3 provides information that the occupants of mansions in the neighborhood of Medan generally worked as private employees and came from the entrepreneur. These results indicatedthat more private employees chose to live in housing that was ready for habitation when compared with the kind of job sharing. Interviews conducted on the samples indicated that civil servants generally had official residences or preferred to build their own houses when compared with housing. Entrepreneurs decidedtheir residence based on the flexibility of business and more likely to choose a place to stay by the function utility in helping their business.

\section{Respondents Based on Latest Education}

Characteristics of respondents based on latest education indicated the level of recent education obtained by the research respondents. The results of research on the last education of the respondents are summarized in Figure 1.

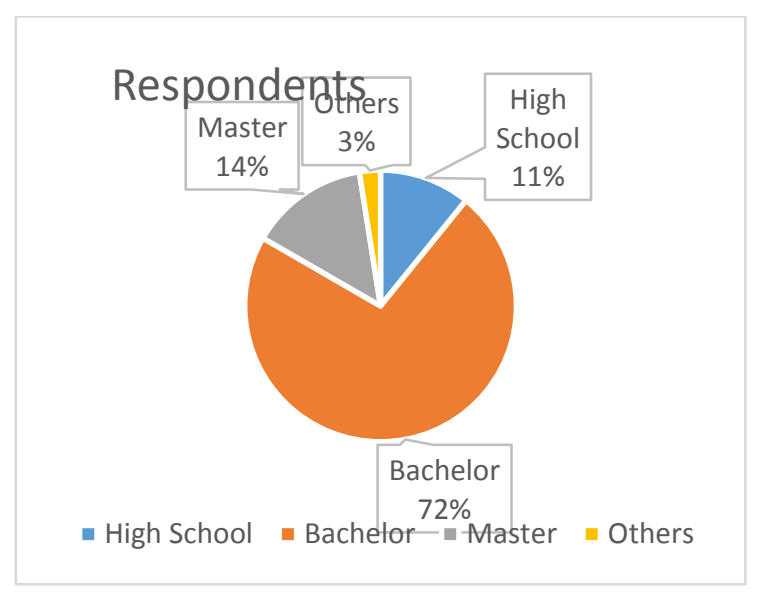
FIGURE 1Respondents Based on Latest
Education

Figure 1 indicates that the majority of respondents were from the last Bachelor degree or undergraduate. Current employment required more graduates and more undergraduates than any other education. Nevertheless, there were still professionals who worked from diploma graduates such as tax professionals. Respondents who came from high school education backgrounds generally worked as entrepreneurs who did not require specific education requirements.

\section{Respondents Based on Acquisition of House}

Housing could be purchased by prospective residents directly from the developeror through an intermediary agent. Agents also played a role in providing residential home rental while developersdid not offer these services. The results related to the status of the acquisition of houses are summarized in Figure 2.

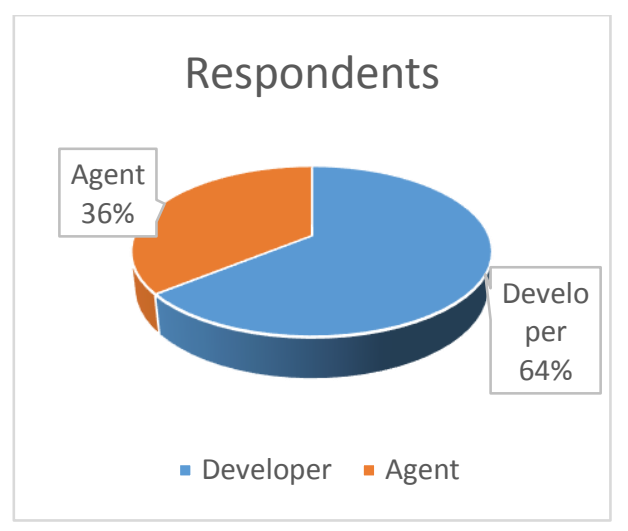

FIGURE 2 Respondents Based on Acquisition of House 
Figure 2 provides information that in general the majority of respondents bought a house directly to the developer $(64 \%)$.Nevertheless, the role of agents in the acquisition of houses was still very important, as much as $36 \%$ of the respondents said in the end they obtained the house through the help of intermediary agents. The ability of communication between agents and developers could be different and some of the respondents were more interested in taking housing from an agent. In addition the agency assisted house ownership with the method of renting a house.

\section{B. The Current Situation}

The location was in the context of the property and the assessment had three main functions that formed the location as accessibility, mobility, and public facilities which were at a particular location. This research added location factor as an environment in assessing value and decision to choose luxury housing in Medan city. Table 2 summarizes the current situation of location variables.

\section{TABLE 4. Descriptive Statistics}

\begin{tabular}{|l|l|c|c|c|}
\hline No & Dimensions & Min & Max & Average \\
\hline 1 & Accessibility & 3.67 & 5.00 & 4.27 \\
\hline 2 & Mobility & 3.67 & 5.00 & 4.06 \\
\hline 3 & Amenity & 3.50 & 5.00 & 3.98 \\
\hline 4 & Environment & 4.00 & 5.00 & 4.38 \\
\hline \multicolumn{4}{|l}{} & $\mathbf{4 . 1 7}$ \\
\hline
\end{tabular}

Table 4 indicates that the location factor played an important role in pushing the decision of choosing a luxury housing and buyer's perception of the value of that housing. Location factors made the value of luxury provided housing became viable from the point of view of consumers. On the average value of the location factor was 4,17 on a scale of 5.00, which meant consumers highly paid attention to its location. In relation to the location functions examined in this study, the lowest consideration factor was location factor based on the facility, i.e. the presence of public facilities around the housing. Although in general the residents of luxury housing still considered the public facilities around the housing were quite complete and easy to achieve, but this factor was the least value factor in average. The most important factor from the consumer's point of view was the environment. Environmental safety as well as free from floods and noise was an important point to be taken in shaping the perceptions of a viable luxury from the point of view of consumers. Accessibility was also very important with the note that a housing should be easily reached, e.g. easily accessed by cars and its location was not far from the highway.

\section{Consumer Rating Ranking on Location Factors}

The rating ranking was based on the total score of responses of housing owners who participated in the study. Each indicator had a score of between 1 and 5. The total score of each indicator was used as a reference in conducting the consumer rating based on the location factor. The results of the study using the ranking method are summarized in Figure 3.

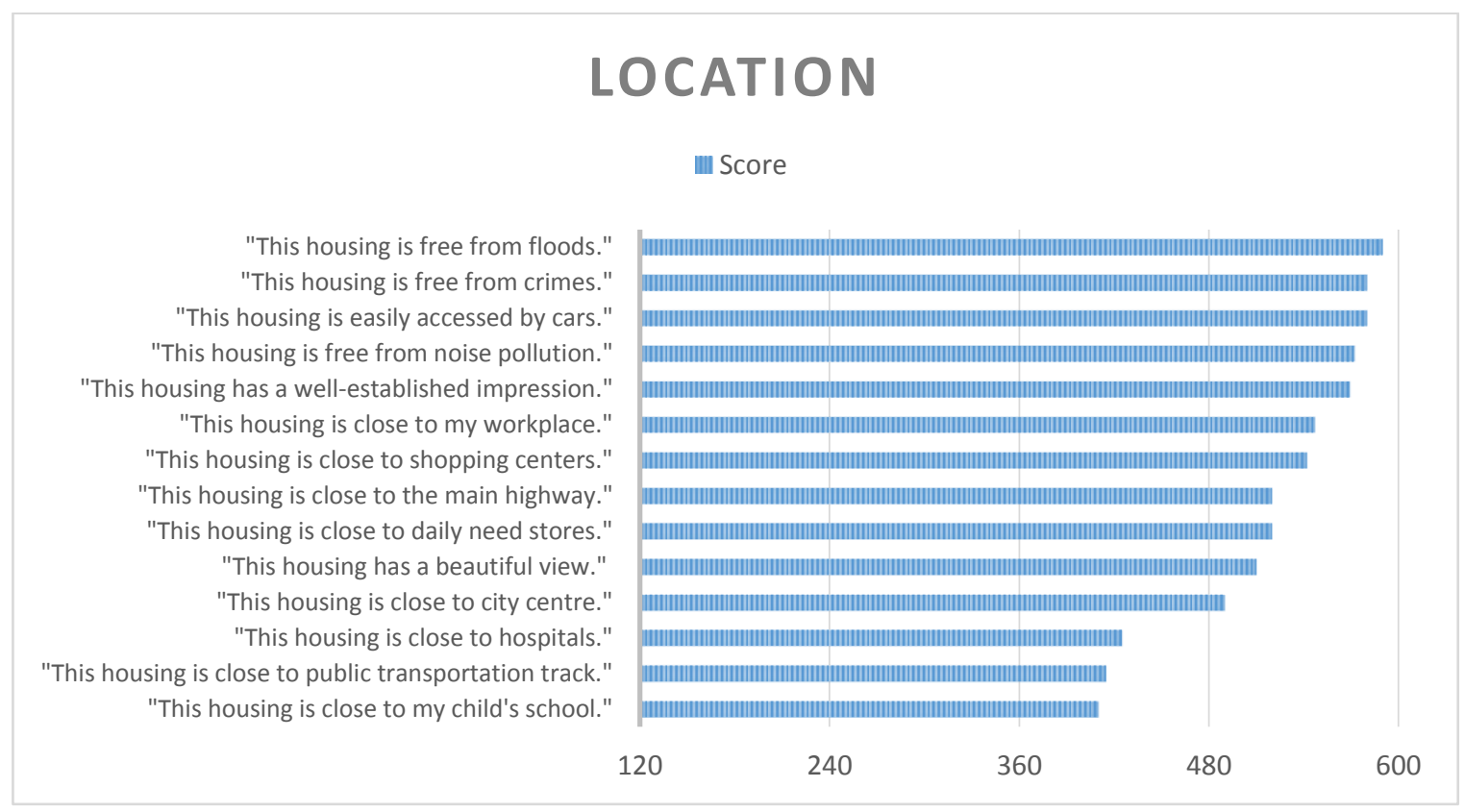

FIGURE 3Ranking of Location Factors Rating 
Figure 3 shows the rating of respondents on each location factor. The number of respondents in this study were 120 respondents. Thus the minimum score or lower limit of the rating score was 120 and the highest score was 600 .

Information from Figure 4 indicates that consumers of luxury housing in Medan city were very concerned of environmental issues, particularly the problem of flooding and crime around the housing. In addition, housing accessibility was also important, for example, should be easily accessed by cars. Although all points in the location factor looked important, the lowest factor from the consumer's point of view was the issue of public facilities such as hospitals and schools. This factor could be accommodated with smooth transportation.

\section{Second Order Analysis}

The data obtained were grouped based on each dimension on the location variable to be evaluated in the dimension stage. Analysis of second order was done with the help SmartPLS 3.0 [23]. Summary of second orderanalysisis given in Table 5.

TABLE 5. Path Estimate for Location

\begin{tabular}{|l|l|c|}
\hline Variable & Dimension & Path Estimate \\
\hline \multirow{3}{*}{ Location } & Accessibility & 0.772 \\
\cline { 2 - 3 } & Mobility & 0.634 \\
\cline { 2 - 3 } & Amenity & 0.701 \\
\cline { 2 - 3 } & Environment & 0.875 \\
\hline
\end{tabular}

Second order analysis evaluates the level of importance of each dimension in explaining a location variable. The results indicated that the variable that played a significant role in explaining the location factor from the point of view of housing buyers was the environmental condition of the housing itself. Research conducted by Cellmer et al. [24] also states that the existence of environmental factors will greatly promote the value of housing. Cellmer concludes that a safe environment and free from the problems that make the price of housing is increasing. In addition to his research,Cellmer states that the beauty of the environment is also a concern in pushing the value of the housing / property.

Environment, in this study discusses the issue of housing freedom from disaster issues such as floods in certain seasons. Based on the rank, the most noticed environmental factor is the flood problem $($ Score $=590)$. The state of natural disasters such as floods will disrupt the activities of the homeowner. Mobility and accessibility can be disrupted by the issue of flooding that occurs in housing. Homeowners are keen to avoid the problem. Furthermore, from the environmental aspect, homeowners highly pay attentionto the crimes happening in the neighborhood (Score $=580$ ) and free from pollution, especially noise (Score = 572). Residence owners are willing to pay more for higher levels of security guarantees. The presence of security posts is greatly appreciated and can encourage their perception of value and willingness to pay more for the housing. Those who have high mobility and have to leave the house within a certain time will feel safer if the crime rate in the area is lower. A safe and guarded home by the developer (with a security post) gives more peace to homeowners when traveling. Ideal housing must also be free from noise pollution so that it can be used properly, e.g. resting without noise disturbance. The lowest location aspect is the impression of the social status of the housing (Score $=569$ ). Although considered as the lowest in the environment class, this aspect is also considered quite important for residence owners. The luxurious and high-class impression of housing becomethe part of the choice of consumers buying houses, especially in the middle to upper class housing.

Accessibility become the second most important factor in choosing a housing. Homeowners argue that a good housing with a difficult access to main roads are detrimental to them. Accessibility is not only valued as the homeowner's necessity, but in the viewpoint of the visiting guest and family. They avoid a housing that is hard to find or reach from the main road.

The existence of public facilities is the third most important factor in the viewpoint of the housing owner. Hospitals, schools, recreation areas, and shopping centers are becoming sought facilities for housing owners. The highest aspect assessed by the housing owner is a shopping center like mall. Proximity to the mall is also a separated consideration for housing owners. This can make it easier for homeowners to shop for the needs, both primary, secondary and tertiary. Modern society has a tendency to visit shopping centers such as mall with a complete service for their shopping and refreshing.

The lowest factor perceived by the housing owner is the mobility problem. Previous research has argued for the problem of working mobility with residences. The study found that the proximity of the workplace has more impact on women than men because they have to take care of home and children so close distance is preferred [25]. In this study, long distances are considered to be well accommodated through easy accessed roads. Remote distances can be accommodated by private vehicles and better time management.

\section{CONCLUSION}

Consumers assess the high feasibility of a housing based on location factors. A good assessment of the location factor makes them choose a housing. Particularly in luxury housing, environmental factors such as freedom from floods and crime are essential. Luxurious impression of the housing is also noticed by consumers. Residential status in luxury housing is also important in attracting consumer perceptions. Access to roads and for cars are a major factor in the accessibility side of luxury housing. Housing should be easily accessible and close to the highway. Facilities, although considerable, but is the lowest factor of the location aspect. Remote facilities can be accommodated by residence owners with adequate transportation.

For the developerswho prepare the ideas of housing, choice of housing location factor itself is very important. Prioritize the access to easy housing and extensive roads so 
that cars can pass in housing and within easy reach. Consider also the flood factor and the crime of the local area before building the housing.

Flood and crime preventions need to be improved. Lately, the problem of flood and crime issue in Medan city are increasing. This will make the consumer or society finds it difficult to take shelter. Therefore, a better coordination and cooperation in managing Medan city is needed.

\section{ACKNOWLEDGMENT}

Authors acknowledge that the study is fully supported and funded by Universitas Sumatera Utara under the auspices of research with the funding of Non-PNBP USU 2017.

\section{REFERENCES}

[1] A.H. Maslow, "A theory of human motivation", Psychological Review, Volume 50, 370-396, 1943, doi: 10.1037/h0054346

[2] S. Źróbek, M. Trojanek, A. Źróbek-Sokolnik, and R. Trojanek, "The influence of environmental factors on property buyers' choice of residential location in Poland", Journal of International Studes, Volume 8, 164-174, 2015, doi: $10.14254 / 2071-8330.2015 / 8-3 / 13$

[3] E. Siahaan, Konsep dan Penerapan Ekonomi Manajerial dalam Bisnis. Medan: USU Press, 2015

[4] F.L. Hall, B. Breston, S. Taylor, "Effects of highway noise on residential property", Values Transport Res Rec., No 686, 3843, 1978

[5] E. Alkay, "The relationship between environmental quality level and housing sale prices in the Istanbul Metropolitan Area", Journal of the Faculty of Architecture, Vol. 6, No 1, 60-76, 2009

[6] The International Valuation Standards 2011, London: International Valuation Standards Council, 2011

[7] W. Safire. "On language: location, location, location' The New York Times, June 28, 2009

[8] J. Kolbe, R. Schulz, M. Wersing and A. Werwatz, "Location, location, location: Extracting location value from house prices", Discussion Paper, Berlin: Deutsches Institut für Wirtschaftsforschung, 2012

[9] I.M. Srour, K.M. Kockelman, T.P. Dunn, "Accessibility indices: A connection to residential land prices and location choices," Transportation Research Record, Vol 1805, No 1, pp. 25-34, 2002

[10] S. Huderek-Glapska, R. Trojanek, "The impact of aircraft noise on house prices", International Journal of Academic Research, Vol. 5, No 3, pp. 397-408, 2013

[11] M. Renigier-Biłozor, R. Wiśniewski, "Real estate market rating - need or necessity?", Real Estate Management and Valuation, Vol 21, No 4, pp. 54-64, 2013

[12] I.R. Lake, A.A. Lovett, I.J. Bateman, I.H. Langford, "Modelling environmental influences on property prices in an urban environment", Comput. Environ. and Urban Systems, Vol. 22, No 2, pp. 121-136, 1998

[13] S. Mitkus, O.R. Šstak, "Preservation of healthy and harmonious residential and work environment during urban development", International Journal of Strategic Property Management, Vol 13, No 4, pp. 339-357, 2009

[14] C.C.M Adriaanse, "Measuring residential satisfaction: a residential environmental satisfaction scale (RESS)", Journal of Housing Built Environment, No 22, pp. 287-304, 2007

[15] C.Y.J. Wendy, Y. Chen, "Consumption preferences and environmental externalities: A hedonic analysis of the housing market in Guangzhou", Geoforum, Vol 38, No 2, pp. 414-431, 2007
[16] P.K.L.Wojnarwsky, Y. Wang, K. Shah, S. Koka, "Factors influencing resident choice of Prosthodontic Residency Program", Journal of Prosthodontics, 1-5, 2017

[17] The Appraisal of Real Estate 13th Edition, Chicago: Appraisal Institute, 2008

[18] H. Andersson, L. Jonsson, M. Ögren, "Property prices and exposure to multiple noise sources: Hedonic regression with road and railway noise", Environmental Resource Economic Springer Science, No 45, pp. 73-89, 2010

[19] P. Kotler, and K.L. Keller, Marketing Management, 14th Edition. New Jersey: Prentice Hall, 2012

[20] D. Willmore, "Determining the value of commercial real estate", Professional Report 3rd Quarter, 2011

[21] B. Lundgren, "Customer-perceived value in residential developments: The case of Hornsberg Strand, Sweden", International Real Estate Review 16(1) pp. 1-27, 2013

[22] C.M. Ringle, S. Wende, and J.M. Becker, SmartPLS 3, Boenningstedt: SmartPLS, http:www.smartpls.com

[23] R. Cellmer, A. Senetra, A. Szczepańska, "The effect of environmental factors on property value", the FIG Working Week 2012

[24] TS06H - Valuation - Environmental Factors 5748, Rome, Italy, 2012

[25] R. Borck, M. Pflüger, and M. Wrede, "A simple theory of industry location and residence choice", IZA Discussion Paper Series, June 2007 